\author{
Klaudia JUSZCZUK ${ }^{1}$ \\ Wioleta KUFLEWSKA ${ }^{2}$
}

\title{
SATISFYING CULTURAL NEEDS IN LUBELSKIE VOIVODESHIP
}

\begin{abstract}
This article refers to the issue related to cultural needs and their indulging. Cultural services are an increasingly intensifying service sector. Acquisition and consumption of services is one of the areas of consumer needs. Satisfying cultural needs is associated with spending free time in a significant way. Knowledge and awareness of culture raise the social position in the long term, so in this sense culture also has an economic overtone, because it affects the quality of life also in the material dimension. The main objective of the work as well as the research being carried out is to determine the level of meeting the cultural needs of the surveyed respondents, as well as the forms of cultural services they use.
\end{abstract}

Keyword: cultural services, cultural needs, acquisition, consumption.

\section{INTRODUCTION}

In a sense, culture is a scheme that imposes a kind of behaviour for a given community. It is closely related to the sphere of consumption, as it is a kind of determinant in the purchasing behaviour of buyers. The key factor when it comes to buying decisions is culture, which has a huge impact on how a product or service is perceived by a modern consumer. In a way, culture is simply an imposed pattern of community behaviour. It is a source of social development, and without it there is no way to speak about structures forming communities and nations. This is because the sense of the world of values or, more broadly, the achievements of people legitimise social structures. As it has been noticed, it causes acceptance of formal and legal norms by changing their institutional letter into emotional ones. It is also necessary to emphasize that culture also acts on the individual and if in the case of society it has functions that legitimise structures and norms, then for the individual the culture has a socialising character. It is often said that children are often brought up, but in essence this means imposing certain norms and behaviour patterns that the community accepts.

\footnotetext{
${ }^{1}$ Klaudia Juszczuk MSc, Pope John Paul II State School of Higher Education in Biała Podlaska, Institute of Economics and Management, Department of Economics, ul. Sidorska 95/97, 21-500 Biała Podlaska; e-mail: juszczuk.kl@ gmail.com. ORCID: 0000-0003-2991-0721.

${ }^{2}$ Wioleta Kuflewska MSc, Pope John Paul II State School of Higher Education in Biała Podlaska, Institute of Economics and Management, Department of Economics, ul. Sidorska 95/97, 21-500 Biała Podlaska; e-mail: wioleta.kuflewska@ interia.pl. ORCID: 0000-0003-3534-3647 (corresponding author).
} 


\section{VARIETY OF CULTURE UNDERSTANDING}

Among many human activities in the broadly understood social life, culture is what in fact significantly differentiates our species from the animal world. The key feature of intelligent beings is the ability to express themselves through contractual signs, shapes or more precisely drawings, texts, music and other forms. However, it should be clearly stated that although colloquially, culture is associated with an art, it is not a synonym. If every art, that is sculpture, painting or literature is a culture or part of culture, then not everything that is culture is art. Culture is generally speaking of the entire output of humanity, that is everything that has been created, that is, good material, art, religion or conceptions and way of thinking, while art is a limited concept to clear activities (Gajda, 2008).

The origin of the term of culture, according to some of the literature of the subject, goes back to the first ancient countries, namely Egypt, Sumer or China. In terms of social psychology, its genesis is much older. Created about 30,000-40,000 years ago rock paintings, some of which have survived to this day, can certainly be considered as a manifestation of cultural activity (Olszewska-Dyoniziak, 2003).

There is a large group of definitions in the literature that sometimes differ from each other in a clear way and at other times in detail. In the case of nominalistic definitions, the criterion is indistinctly formulated and may assume a different typology depending on the researcher. The definition may include the words formulated by D. Malinowski, who says that "culture is an integral whole, which consists of tools, consumer goods, human ideas, crafts, beliefs, customs and community structures". (Nowicka, 2009).

The second group of definitions are so-called historical ones. The term is taken from the fact that proponents of this typology emphasise the factor related to the mechanism of shaping and transmitting culture, sometimes called the factor of tradition. The author of one of such definitions is S. Czarnowski, who states that "culture is a collective good and heritage, the fruit of the creative effort of countless generations, it can be talked about when the discovery or invention is preserved and passed down as a part of the collective achievements of the community" (Jakubowski, 2012).

The third group is the so-called normative definitions, where the selected behaviours of people are assigned to norms, standards and values. This means that adapting an individual to specific norms has a cultural behaviour feature. T. Parsons recognises culture as passed and created model of ideas, values and content of symbolically important systems that shape human behavior (Kłoskowska, 2007).

In turn, the groups of psychological definitions attach particular importance to the psychological mechanisms of creating cultures, and thus learning, forming habits and externalising the norms in force in a given community and what is important for it to be recognised. The importance of imitation and learning skills is emphasised here. The definition of S. Ossowski seems to be clear, claiming that culture is a group of psychological dispositions in a given community and communicated by social contact (Herder, 2000).

It seems that, after all, the definitions quoted above do not constitute a simple and lucid expression of the concept of culture. Perhaps the most universal is the accent approach, that this is simply a kind of creativity that aims to convey symbolic and practical significance, which is a legacy for the next generations, i.e. cultural (Benedict, 2002). 


\section{DETERMINANTS OF SATISFYING CULTURAL NEEDS}

The consumption of culture is strongly dependent on economic factors, which is manifested by the fact that in richer societies, the frequency of communing with culture increases, because basic needs do not show too many difficulties to satisfy them. However, if it were only about economic issues, one could come to the conclusion that economic growth, translating into the growing purchasing power of consumers, will be conducive to the dynamics of demand for cultural products (Rudnicki, 2000).

Analysing the process of satisfying cultural needs, it can be seen that other social conditions also work here. In a nutshell, internal and external determinants are distinguished here. At the very beginning, there is a complex process that ultimately leads to the ultimate use of culture. In the first place there must be a sense of cultural need. Then the search for information takes place. In the next sequence there is an assessment of the variants of how to meet the need, if it appeared in the earlier stages and finally the final decision and following feelings (Bombol, Dąbrowska, 2003).

As far as internal determinants are concerned, attention should be paid to issues strongly related to human personality. According to A. Maslow's theory, culture is a higher level of hierarchy of needs. Although, on the one hand, it is not only about satisfying aesthetic needs, but also about culture and raising society, at the time of economic crises, the first thing that people give up regardless of their preferences and cultural competences is the use of this area. An important fact is that some people who are in a specific social group participate in cultural events due to the fact that regardless of their own preferences, it has the feature of confirming their affiliation. Another external motive, similar to cultural participation, understood as confirmation of identification in a given social group is prestige (Rudnicki, 2000).

For some people who achieve high material status, culture, regardless of the actual taste or choices, becomes a kind of confirmation of social status in the sense that at some level it is simply not proper to have an extensive home library or financial support for the theater or gallery. It should be added that these motives of cultural participation and prestige do not have to be associated with the actual involvement in art, although, they can. Another internal motive that social psychology speaks is the desire to socialise, which is made up of more unofficial formulas that foster looser talks on the basis of theater art, cinema premiere or other cultural events (Rudnicki, 2000).

However, these internal determinants are subjective in nature because they may result from actual involvement in art or they may also be an expression of a certain imitation resulting from the social position and related norms. Another example of internal factors are personality ones. They result from elevated cultural capital, aesthetic thrills, the need for intellectual experience or even curiosity. It should be added that this type of participation may have either a paid participation formula or a selection of specific radio, television or internet content programs. Generally, internal determinants are divided into socio-economic factors related to the personality, social position and cultural context of the given environment (Rudnicki, 2000).

The second category is external determinants. In this case, the economic factor is obviously a perception of culture as a market element. There is a correlation between the economic development of a given region and the use and accessibility of cultural services (Bombol, Dąbrowska, 2003). However, it is not as strong as it seemed a few decades earlier. 
It should not be forgotten that the important issues shaping the ways of using culture are the cultural needs of consumers, called colloquial tastes in everyday language (Noga, 2014).

If it comes from a purely economic perspective, then any form of participation in culture, regardless of the evaluation of its products, is significant and positive, because people participate in broadly understood cultural development, strengthening its economic foundations. On the other hand, the criterion of choosing cultural goods can in and of itself testify to some environmental or social affiliation, and in that sense, what we choose, even if it is unconscious, defines the individual, and thus creates a certain cultural code. It should be added that an important external determinant are the institutional activities of the state, the most important of them is the preparation of people to use culture primarily in intellectual terms by the school or the education system (Noga, 2014).

Participation in culture is an indispensable part of every human being, but it changes only with age. It indicates that with the beginning of human life, it grows under the influence of the science of everything and lasts until death.

\section{CULTURAL SERVICES IN THE LIGHT OF OWN RESEARCH}

The general objective of the research was to determine the level of meeting the cultural needs of the surveyed respondents, as well as the forms of cultural services they use. The research was carried out in March 2019 in the group of 201 respondents using the questionnaire. The selection of the sample for the research was on-target selection, the target group was people who were 18 years of age and co-create a household in the Lublin voivodeship.

Among the group of 201 respondents $-37.8 \%$ were men (76 people), while the number of women participating in the survey stood at $62.2 \%$, which was 125 people. In the case of cultural needs, this is important because men and women may be guided by a slightly different perception of cultural needs.

When analysing respondents by age, it is possible to specify four main age categories. These include people aged 18 to 24 and respondents in the range of 25-34, 35-44 and above 45 years of age. Separation of several age categories allows you to look at the area under investigation from different perspectives. We are talking here about the fact that different things are perceived by younger people, and the older people, who already have certain life experience, The vast majority were people who did not exceed 35 years of age, over $50 \%$ of the surveyed population (155 people), 66 of whom are 24 years of age, and 89 people are in the range of 25-34. A smaller number are participants who were in the range of 35-44, while only 9 people are respondents over 45 years of age.

\subsection{Needs and level of their satisfying}

When assessing the level at which needs are met in households, respondents were divided into general groups, each of which was asked to indicate the appropriate frequency, in this case the level of satisfaction. The respondents received previously prepared categories of needs, including: food and non-alcoholic beverages, clothing and footwear, use of housing and energy carriers, health, transport, education, culture, tourism and recreation, and spirituous beverage as well as tobacco products.

These needs are, of course, only the most common in every human and household life, although the palette of needs that each person can have is much wider and also diverse. However, these general indicators allow to determine these regularities. As regards the very high level of satisfaction, food and alcohol-free beverages were ranked first in a clear and 
dominant way, for 201 respondents as many as $67.3 \%$ of people indicated a very high level of satisfaction and an additional $27.9 \%$ high. This means that a total of $95.2 \%$ of all respondents meet this basic need in at least a high way. Additionally, this proves taking into account the research carried out regularly over the last 30 years, how the rate of living has risen.

In the case of needs that can be considered additional, i.e. culture, education or, for example, clothing or footwear, they are satisfied secondly. It is necessary to complete that it is not a second order in the sense of cultural needs or general human needs, but in the economic sense. To some extent, one can accept the thesis that satisfying the needs of respondents, apart from food and housing, is determined by the amount of income.

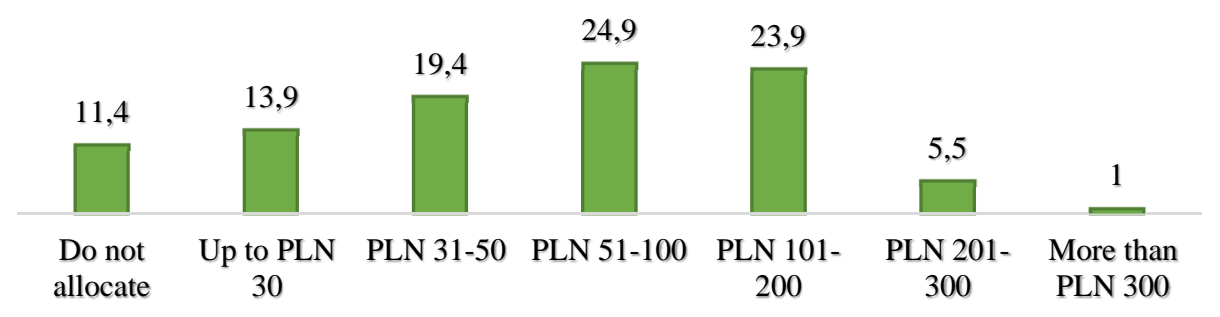

Figure 1. The amount of monthly financial resources spent by respondents on the purchase of cultural goods / participation in culture (\%)

Source: own study based on the results of the research.

People using or participating in cultural property are obliged to bear costs related to the discussed area for some time. 23 people $(11.4 \%)$ do not allocate any financial resources in this area. This means that most likely they are respondents who do not participate in the broadly defined culture, hence the lack of costs.

Slightly fewer respondents, 28 people spend up to PLN 30 a month, 39 people spend from PLN 31 to PLN 50, while from PLN 51 to PLN 100, about 1/4 of those surveyed, or 50 people. As for larger amounts up to PLN 200, costs are borne by 48 people, up to PLN 300 for 11 people, and more than PLN 300 a month for 2 people.

Expenses are mainly correlated with the material status, the professional situation and even age. All of these components are related because people with lower incomes must first meet the needs of the first order. On the other hand, respondents with higher status may allow for higher spending in the field of culture. In contrast, younger people are more likely to use cultural goods rather than older people, which shows that each age group has different priorities in terms of cultural needs.

\subsection{Participation in the forms of cultural life and evaluation of the offer of culture institutions}

In this part, free time has been spelled out, limiting respondents to forms of cultural life. This means that other forms of spending free time were excluded, asking the respondents to indicate the frequency of each form of participation in the broader culture. The most active participation is 5 to 7 times a year or 8 times a year. Participation was rare for individual events 2 to 4 times a year or 1 year and not at all. It should start with the 
approximation of the results of the most frequent cultural activities among the 201 respondents of this research.

The highest activity in the category of more than 8 times a year was given to the cinema, which was marked by $25.9 \%$ of people, with another $25.9 \%$ doing it 5 to 7 times a year. In the next positions, there were outputs to cafes, pubs or restaurants, respectively $47.3 \%$ and $16.4 \%$ people, going to clubs or discos respectively $23.4 \%$ and $16.9 \%$ of people and participation in music concerts and festivals $19.4 \%$ and $13.4 \%$ of people. It can be concluded that after the analysis of cultural activities is the growing dominance of socialising and going to broadly understood cafes or restaurants, which also does not exclude social activity and can be treated in a way as one category. In addition, the younger the age group, the more the category of cinemas, clubs, discos and music concerts increases. The remaining forms are relatively rare regardless of the age category, which can be explained by economic considerations, but perhaps by lack of cultural competence. It is difficult to treat participation in picnics, exhibitions in galleries or meetings with interesting people as expensive.

Table 1. Offers of institutions / organisations respondents use (\%)

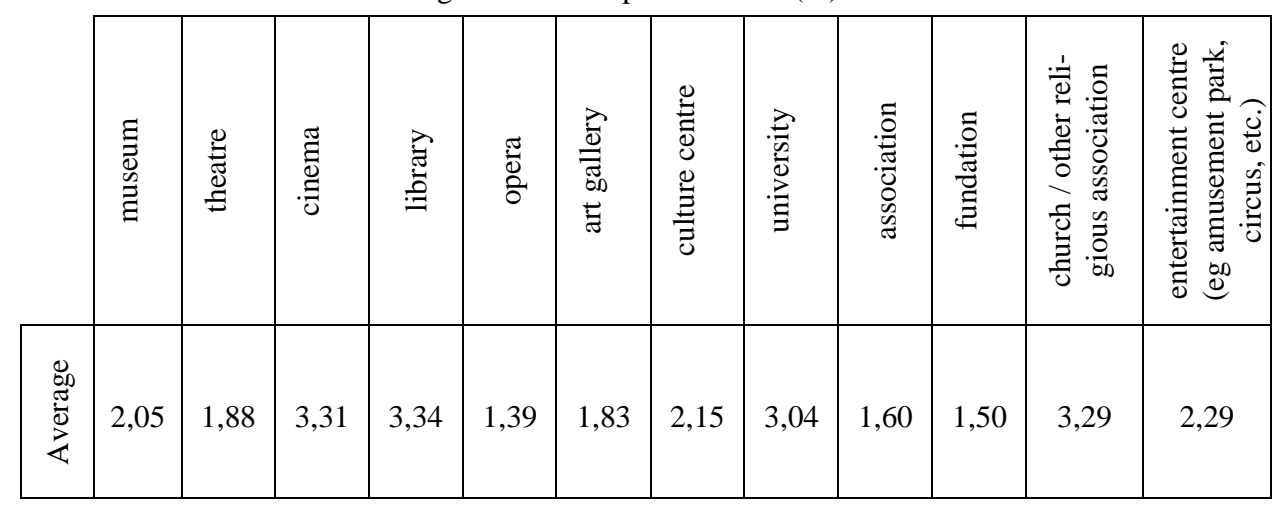

Source: own study based on the results of the research.

Regarding the offers of institutions / organizations that individual respondents use in the Lublin voivodeship or elsewhere, respondents were asked to select individual categories and to assign activities on a five-point scale from never to very often.

Library, church and other religious association, as well as a university, these four institutions are definitely dominant in the sense of using them. What can be clearly seen is almost a division into exactly half between strictly cultural institutions (cinema and library) and those that cannot be defined in such a way, but belonging to culture in a broad and therefore social sense.

It is worth paying attention to whether the availability of institutions undertaking cultural activities influences the needs of the surveyed people. More than half responded answered ,yes", as $57.7 \%$ of the surveyed, this result can be considered quite low, especially if it is noted that $22.4 \%$ answered ,do not know”. One can get the impression that the respondents could not decide whether the availability itself affects the satisfaction of cultural needs or whether attitude and activity are more important. If someone wants to use institu- 
tions that undertake activities related to culture, then it is not an obstacle for him to overcome a few kilometers.

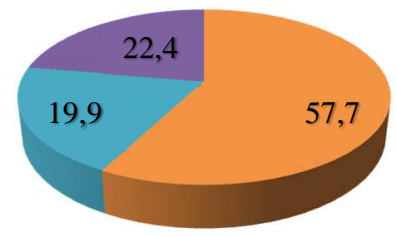

$\square$ Yes

- No

Do not know

Figure 2. The influence of available institutions/organizations on satisfying cultural needs (\%)

Source: own study based on the results of the research.

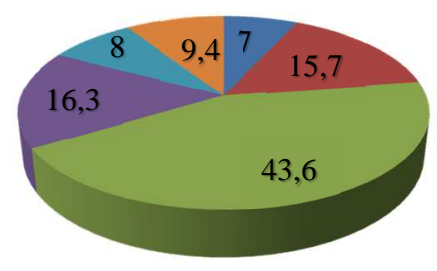

\author{
- Very low \\ - Low \\ Neither high nor low \\ - High \\ - Very high \\ I have no opinion
}

Figure 3. Evaluation of the offer of cultural institutions operating in the respondents' place of residence $(\%)$

Source: own study based on the results of the research.

Answers to this question should be divided into two parts. The first of these is the opinion of people actually participating in culture, while the second part should be treated as a kind of common opinion, though sporadically confirmed by their own presence. Therefore, it should be considered crucial that the largest number of respondents, as much as $43.69 \%$ do not recognize the offer of cultural institutions, neither high nor low. In practice, this means that the majority of respondents (almost half of them) simply have no opinion on the topic, as it is not regularly or not widely used in this type of offer. Add to the fact that $9.4 \%$ of people said directly that there is no opinion on this subject, it only confirms the original thesis, that someone who does not participate naturally has difficulty in assessing. Therefore, taking into account other responses, it seems that they only reflect the actual opinion on participation.

Referring to the influence of culture on the quality of life, $66.7 \%$ of respondents felt that this was a positive impact. Nevertheless, it might seem based on some simplified social perceptions that even if a significant part of society does not use cultural institutions, at least it believes that it has a positive impact on the quality of life. 


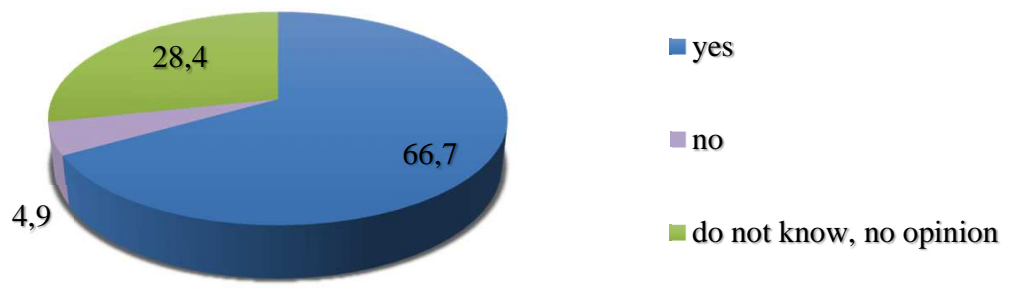

Figure 4. The influence of culture on the quality of life (\%)

Source: Own study based on the results of the research.

Among those who took part in the study on the open-ended question "why culture has a positive impact on the quality of life" only those respondents who gave an affirmative answer to the previous question were answered, that is $66.7 \%$ of respondents. The most frequent responses are sensitization (49 people), personality development (25 people), widening of horizons (20 people). On slightly further positions with indications of less than 20 people there was relaxation, mental experience and mood improvement.

One can clearly see here the very active participants of culture, and that they perceive it not only as social events, but also something that can be translated into broadly understood cultural and social competences. In all studies carried out on a global scale, it has been proven many times that people who grow in a more culturally competent environment have fewer barriers to achieving their intentions and professional or social ambitions.

Table 1. Cultural institutions in short supply in the place of residence of individual respondents (\%)

\begin{tabular}{|l|c|c|c|c|}
\hline & yes & no & no need & total \\
\hline theatre & 40,3 & 45,3 & 14,4 & 100,0 \\
\hline opera & 31,8 & 43,8 & 24,4 & 100,0 \\
\hline $\begin{array}{l}\text { institution that disseminates culture } \\
\text { through education and artistic activities }\end{array}$ & 47,8 & 47,8 & 4,4 & 100,0 \\
\hline $\begin{array}{l}\text { institution presenting culture and } \\
\text { curiosities from distant countries, e.g. } \\
\text { Japan, China, Africa etc. }\end{array}$ & 42,3 & 39,3 & 18,4 & 100,0 \\
\hline $\begin{array}{l}\text { performance hall allows organising } \\
\text { spectacular events }\end{array}$ & 48,8 & 46,8 & 4,4 & 100,0 \\
\hline $\begin{array}{l}\text { sports facilities / stadium, swimming } \\
\text { pools etc. }\end{array}$ & 48,8 & 47,3 & 3,9 & 100,0 \\
\hline $\begin{array}{l}\text { intimate cinema with an ambitious } \\
\text { repertoire }\end{array}$ & 37,8 & 56,7 & 5,5 & 100,0 \\
\hline music clubs and disco & 35,8 & 58,2 & 6,0 & 100,0 \\
\hline museum & 24,9 & 68,7 & 6,4 & 100,0 \\
\hline pub and cafe & 33,8 & 63,7 & 2,5 & 100,0 \\
\hline aqua park & 54,8 & 40,8 & 4,4 & 100,0 \\
\hline
\end{tabular}

Source: own study based on the results of the research. 
When assessing the level of cultural events organised in the place of residence, the respondents in the largest group, as many as $45.8 \%$ responded that they rate these events neither high nor low (92 people) should be added to 7 people who have no opinion on this topic. Therefore, it makes a total assessment that half of the respondents cannot in any way determine the level of events.

Considering which cultural institutions are missing in the place inhabited by the respondents, they were given the opportunity to indicate the differentiated answers for each category. Everyone could choose whether the given institution is a missing, non-existent or a variant that is not needed at all.

As for the most needed institutions, which is missing in the numerical sense, the largest number of people $(54.8 \%)$ pointed to the aqua park. The next items included institutions popularising culture through education and artistic activities, as indicated by $47.8 \%$ of people and a performance hall and sports facilities, which was mentioned by $48.8 \%$ of people. It is clearly visible that the dominant response related to the aqua park is the result of a lack of awareness of the essence of cultural institutions among a large number of respondents.

Objects such as an aqua park and stadiums are not subjects of culture, but entertainment, though having social justification. It can be presumed that among those $54.8 \%$ of people who mentioned the aqua park, a large part is not participating in culture. Hence their problem with defining and distinguishing the aqua park from, for example, the museum, which was indicated by $24.9 \%$ of the respondents.

Considering the opinion of respondents regarding what features should be possessed by a modern cultural institution, the first place has been taken advantage of by using modern technologies, which were marked by $94.5 \%$ of people. In practice, this means that such an option, which is the most important for modern cultural institutions, has been indicated both by those who participate (participate) in cultural events as passive.

It seems that there is a common denominator in this place, based on the realisation of the fact that digital technologies are an integral part of the modern world, including culture. The next items included a varied cultural offer for children, youth and adults (93.5\% of indications), implementation of programs for the disabled people (91\%) and a combination of artistic and educational functions (95\%). It should be noted that some respondents still have problems with defining cultural phenomena. It is difficult to recognize that the features which a modern cultural institution should have are the implementation of a program for the disabled or combining artistic and educational functions. It is true that the implementation of the program for the disabled is an important integration element, but this cannot be treated as a cultural offer of the strict sense, just like the joint education and culture in the guideline for children and youth. Nevertheless, the remaining responses, although marked by a slightly smaller number of respondents, are more in line with the functions of a modern cultural institution, for example, to perform an artistic function, offer outside the walls of the institution or be open to other cultural traditions or nations.

\section{SUMMARY}

Culture is a kind of sphere that surrounds human on every side, both in everyday activities and while spending free time. For the vast majority of respondents, free time is very important. This is important because those respondents who realise the importance of free time are people who use cultural goods to a large extent and satisfy cultural needs. 
There are a number of factors that influence the use of cultural goods and thus the satisfying of cultural needs. One of them is the place of residence. Larger institutions and organizations dealing with culture are usually located in big cities. Age is another factor. This means that people who have participated in the study for the most part are students who have different cultural needs than older people. Therefore, it is not surprising that they consider going to a disco, club, cafe, pub, etc. as a form of cultural life. Also important are financial resources, which do not allow to meet cultural needs by people with low financial status in the same scope as people with higher incomes.

In summary, culture is an attribute of human, because only human being can create it. Culture integrates with the local community as it mediates between the human environment and the human being. Culture affects not only personality, but also human activity. Therefore, people should take care of this area and, above all, take an active part in it.

\section{REFERENCES}

Benedict, R. (2002). Wzory kultury, Warszawa: Muza.

Bombol, M., Dąbrowska, A. (2003). Czas wolny. Konsument. Rynek. Marketing, Warszawa: K.E. Liber S.C.

Gajda, J. (2008). Antropologia kulturowa. Wprowadzenie do wiedzy o kulturze, Kraków: Impuls. Herder, J.G. (2000). Myśli o filozofii dziejów (wybór), Warszawa: Elipsa.

Jakubowski, W. (2012). Kultura jako przestrzeń edukacyjna, Kraków: Impuls.

Kłoskowska, A. (2007). Socjologia kultury, Warszawa: Wydawnictwo Naukowe PWN.

Rudnicki, L. (2000). Zachowania konsumentów na rynku, Warszawa: Wydawnictwo Naukowe PWN.

Malinowski, B. (2000). Kultura i jej przemiany, Warszawa: Wydawnictwo Naukowe PWN.

Noga, M. (2014). Kultura a ekonomia, Warszawa: CeDeWu.

Nowicka, E., Głowacka-Grajper M., red. (2009). Świat człowieka, świat kultury. Antologia tekstów klasycznej antropologii, Warszawa: Wydawnictwo Naukowe PWN.

Olszewska-Dyoniziak, B. (2003). Człowiek kultura osobowość, Wrocław: Alta.

DOI: 10.7862/rz.2019.mmr.17

The text was submitted to the editorial office: July 2019.

The text was accepted for publication: October 2019. 